\title{
Comparative Toxicity of Nitenpyrem and Neem Oil Against Amrasca biguttula biguttula in Okra
}

\section{Zulnorain Sajid', Muhammad Anwar Ul Haq ${ }^{2}$, Qasim Farooq ${ }^{3}$, Yaqoob Sultan², Usama Sher ${ }^{4}$, Muhammad Tayeb ${ }^{5}$ and Muhammad Ramzan 6}

(1) Department of Entomology, PMAS Arid Agriculture University, Rawalpindi, Pakistan;

(2) Department of Horticulture, Bahauddin Zakariya University, Multan, Pakistan; (3) Department of Botany, University of Agriculture, Faisalabad, Pakistan; (4) Department of Agronomy, Bahauddin Zakariya University, Multan, Pakistan;

(5) Department of Plant Protection, University of Agriculture Peshawar, Pakistan; (6) State key Laboratory for Biology of Plant Diseases and Insect Pests, Institute of Plant Protection, Chinese Academy of Agricultural Sciences,

Beijing 100193, China, Email: ramzan.mnsua@gmail.com

\begin{abstract}
Sajid, Z., M.A. Ul Haq, Q. Farooq, Y. Sultan, U. Sher, M. Tayyeb and M. Ramzan. 2021. Comparative Toxicity of Nitenpyrem and Neem Oil Against Amrasca biguttula biguttula in Okra. Arab Journal of Plant Protection, 39(3): 210-214. https://doi.org/10.22268/AJPP-039.3.210214

The Jassid, Amarasca bigutulla bigutullaa is an important sucking pest of the okra crop. An experimental study was conducted during 2018 to check the comparative toxicity of nitenpyrem and neem oil against jassid under okra field conditions. The study revealed that 24 hours after treatment, nitenpyrem was found more toxic and effective with maximum reduction of jassid population (72.15\%). Whereas, 120 hours after treatment with $4 \%$ neem oil, $15.05 \%$ jassid reduction was observed. The mortality rate of the jassid was increased with increasing in time after application of chemical insecticides. The study concluded that insecticide was most toxic and gives higher mortality of jassid as compared to neem oil.

Keywords: Abelmoschus esculentus, Malvaceae, Amarasca bigutulla bigutullaa, botanicals, insecticides, Pakistan.
\end{abstract}

\section{Introduction}

Okra (Abelmoschus esculentus L.) belongs to Malvaceae family, is grown as a main vegetable (Kumar et al., 2010) grown in tropical and subtropical countries of the world including Pakistan (Schippers, 2000), in two growing seasons annually (Mahmood et al., 2014). Okra is an important source of energy, vitamins, protein, carbohydrate, iodine and mineral (Kahlon et al., 2007; Saifullah \& Rabbani, 2009). Its production is dependent on various factors such as varieties, irrigation and balanced fertilizer, in addition to many other factors such as insect pest, plant viruses, diseases and poor soil fertility (Dhaliwal, 2004) which can decrease its production in various places of the world.

More than 48 insect species have been recorded as a pest infesting okra (Fajinmi \& Fajinmi, 2010). Okra could be infested by both biting insect pests like fruit worms and sucking pests that that feed on cell sap (Fajinmi \& Fajinmi, 2010). The main serious sucking and chewing insect pests of okra are Amrasca devastans, Aphis gossypii, Thrips tabaci, Bemisia tabaci and Helicoverpa armigera, Earias vittella (Anaso \& Lale, 2001; Singh et al., 2013).

Among all insect pests, (Singh et al., 2013) the Jassid (Amrasca devastans) is considered as major and serious pest of okra throughout the world (Dhandapani et al., 2003). Both adults and nymph jassid stages suck the cell sap from the ventral surface of plant leaves. During severe infestation, jassid inject toxic chemicals (toxin) to the crop, which cause

https://doi.org/10.22268/AJPP-039.3.210214

C 2021 Arab Society for Plant Protection الجمعية العربية لوقاية النبات curling and stunting of crop (Ramzan et al., 2020; Singh et al., 2008).

Severe jassid attack can lead to $54.04 \%$ yield loss. Several management strategies have been adopted to control this notorious pest throughout the world. Among all adopted methods, chemical control is mostly used as principle strategy against insect pest due to quick action toward the target insect pests. However, the chemical method has proved harmful for many non-targeted fauna (Hassan et al., 2007), in addition to its negative impact on the environment (Malik et al., 2015). Furthermore, the intensive application of the same group of insecticides against the target pest can enhance the development of resistance to the chemicals used (Murtaza et al., 2019; Rajput, 2004).

On the other hand, plant natural extracts are considered as ecofriendly, species specific, biodegradable, nontoxic to humans, animals, birds and nontarget species. These could be derived from barks, seed, roots, leaves and fruits of various plants, and many of them are now being used to control insect pests and proved to be effective in managing insect pests in many countries. The various biopesticides such as Azadirachta indica showed to have repellent and anti-feeding properties were tested against insect pests (Khattak et al., 2006; Senthil Nathan et al., 2009).

Integrated pest management (IPM) which is the most important eco-friendly and cost-effective method to control insect pests (Memon et al., 2004). Using biopesticides as a control component in the IPM strategy proved to be effective, economical, and not harmful to natural enemies (Sharma \& Ortiz, 2002). For this purpose, the current study 
was conducted in okra field to check the comparative toxicity of neem oil with Nitenpyrem against the okra Jassid.

\section{Materials and Methods}

\section{Experimental design}

An experimental trial was conducted in a farmer's field in Multan, Pakistan to check the comparative toxicity of neem oil and the insecticide (Nitenpyrem 50\%WG) for ecofriendly management of jassids which attack the okra crop. Randomized complete block design (RCBD) was used with four replications each with seven treatments, including control. The size of individual plots was $3 \times 3$ meters. Okra variety, Sada Bahar was sown on ridges. The rows were 60 $\mathrm{cm}$ apart and the distance between plants in the rows was 30 $\mathrm{cm}$. The routine management practices were applied throughout the trial.

\section{Source of neem oil and insecticide}

Neem oil was brought from Department of Entomology, University of Agriculture, Faisalabad, whereas the chemical insecticide was purchased from a nearby pesticide shop.

Bioassay of the neem oil and the chemical insecticides Different concentrations of neem oil were prepared and applied to the crop when the pest population reached the economic threshold (ETL) level. Neem oil with 1, 2, 3, 4, 5 percent concentrations and Nitenpyrem 50\%WG were applied to the crop @ 100 ml/ha by using a knapsack sprayer.

\section{Data collection}

Jassid population was recorded weekly for each treatment. Data was documented 24, 48, 72, 96 and $120 \mathrm{~h}$ after treatment. For this purpose, six plants were randomly selected from the central two rows in each treatment and upper, middle and lower leaves of selected plants were examined to count pest population. Mean and percent reduction of pest population was calculated according to Rehman et al. (2015).

\section{Statistical analysis}

Data was statistically analyzed by using statistical analysis package MSTATC. F ratio was also determined by least significance difference (LSD) test at 0.05 probability level to record the statistically significant difference among treatments.

\section{Results}

Toxicity of nitenpyrem and neem oil against the okra jassid in the field after the first spray is presented in Table 1. After 24 hours of treatment, the insecticide Nitenpyrem (T6) was found the most effective with maximum reduction of jassid population reached to $(70.42 \%)$. While neem oil at $1 \%$ (T1) was least effective against jassid population. The maximum reduction of jassid was $74.56 \%$ recorded after 48 hours, post treatment. Pest population was reduced with increase in chemical percentage in neem oil. After 96 hours of treatment, the maximum jassid reduction was (66.78) observed at T4 treatment.

It was observed that jassid reduction in $\mathrm{T} 5$ and $\mathrm{T} 4$ was found significantly different from $\mathrm{T} 1, \mathrm{~T} 2, \mathrm{~T} 3$ and $\mathrm{T} 7$ at 5\% level of significance. The reduction in $\mathrm{t}$ jassid population was decreased at all treatment and reached to $30.35 \%$, with Nitenpyrem after 120 hours of treatment. The pest population was higher in control treatment as compared to treated plots. All treatments were found most effective and showed best control against pest population after $72 \mathrm{hr}$. of treatment.

Toxicity of nitenpyrem and neem oil against jassid in okra field after $2^{\text {nd }}$ spray is given (Table 2). After 24 hours of treatment, nitenpyrem (T6) was found more toxic and effective with maximum reduction of jassid (72.15\%). while Neem oil at $1 \%$ (T1) was least effective treatment against jassid. The maximum reduction $(72.15 \%)$ of jassid population was found in treatment T6 I was statistically similar with T4 and T5 treatment with 63.66 and $65.77 \%$ reduction after 24 hours. After 48 hours of application, all treatments were significantly different from control. After 96 hours, T6 was most effective followed by T5, T4, T3, T2 and T1 treatment.

Table 1. Reduction (\%) in okra jassid population following the first spray of different treatments.

\begin{tabular}{|c|c|c|c|c|c|c|}
\hline \multirow{2}{*}{$\begin{array}{l}\text { Treatment } \\
\text { code }\end{array}$} & \multirow[b]{2}{*}{ Treatments } & \multicolumn{5}{|c|}{ Period after first spray } \\
\hline & & 24 hours & 48 hours & 72 hours & 96 hours & 120 hours \\
\hline $\mathrm{T}_{1}$ Neem oil & $1 \%$ & $30.34 \mathrm{~d}$ & $34.42 \mathrm{~d}$ & $42.30 \mathrm{~d}$ & $49.73 \mathrm{~d}$ & $6.97 \mathrm{~d}$ \\
\hline $\mathrm{T}_{2}$ Neem oil & $2 \%$ & $34.57 \mathrm{c}$ & $47.72 \mathrm{c}$ & $45.76 \mathrm{bc}$ & $54.62 \mathrm{c}$ & $8.63 \mathrm{~d}$ \\
\hline $\mathrm{T}_{3}$ Neem oil & $3 \%$ & $40.62 \mathrm{~b}$ & $52.35 \mathrm{~b}$ & $55.66 \mathrm{~b}$ & $57.78 \mathrm{~b}$ & $6.88 \mathrm{~d}$ \\
\hline $\mathrm{T}_{4}$ Neem oil & $4 \%$ & $60.52 \mathrm{a}$ & $67.36 \mathrm{a}$ & $68.15 \mathrm{a}$ & $66.78 \mathrm{a}$ & $12.98 \mathrm{c}$ \\
\hline $\mathrm{T}_{5}$ Neem oil & $5 \%$ & $66.53 \mathrm{a}$ & $69.16 \mathrm{a}$ & $70.01 \mathrm{a}$ & 64.99 a & $19.55 \mathrm{~b}$ \\
\hline $\mathrm{T}_{6}$ Nitenpyrem & Nitenpyrem & $70.42 \mathrm{a}$ & $74.56 \mathrm{a}$ & $78.02 \mathrm{a}$ & $58.15 \mathrm{a}$ & $30.35 \mathrm{a}$ \\
\hline $\mathrm{T}_{7}$ Water & Control & $4.33 \mathrm{e}$ & $13.44 \mathrm{e}$ & $11.67 \mathrm{e}$ & $-1.06 \mathrm{e}$ & $-10.43 \mathrm{e}$ \\
\hline LSD value & & 4.12 & 4.23 & 4.10 & 5.11 & 4.00 \\
\hline
\end{tabular}

Means followed by the same letters in the same column are not significantly different at $\mathrm{P}=0.05$.

Values with "_" symbol represent an increase in the pest population. 
Table 2. Reduction (\%) in okra jassid population following the second spray of different treatments.

\begin{tabular}{|c|c|c|c|c|c|c|}
\hline \multirow{2}{*}{$\begin{array}{l}\text { Treatment } \\
\text { code }\end{array}$} & \multirow[b]{2}{*}{ Treatments } & \multicolumn{5}{|c|}{ Period after second spray } \\
\hline & & 24 hours & 48 hours & 72 hours & 96 hours & 120 hours \\
\hline $\mathrm{T}_{1}$ Neem oil & $1 \%$ & $29.60 \mathrm{~d}$ & $33.51 \mathrm{~d}$ & $35.56 \mathrm{~d}$ & $41.42 \mathrm{~d}$ & $8.12 \mathrm{c}$ \\
\hline $\mathrm{T}_{2}$ Neem oil & $2 \%$ & $31.00 \mathrm{c}$ & $38.45 \mathrm{c}$ & $40.26 \mathrm{c}$ & $43.78 \mathrm{c}$ & $8.64 \mathrm{c}$ \\
\hline $\mathrm{T}_{3}$ Neem oil & $3 \%$ & $37.12 \mathrm{~b}$ & $40.32 \mathrm{~b}$ & $44.01 \mathrm{~b}$ & $46.83 \mathrm{~b}$ & $12.77 \mathrm{~b}$ \\
\hline $\mathrm{T}_{4}$ Neem oil & $4 \%$ & $63.66 \mathrm{a}$ & $69.74 \mathrm{a}$ & $70.25 \mathrm{a}$ & $67.77 \mathrm{a}$ & $15.05 \mathrm{a}$ \\
\hline $\mathrm{T}_{5}$ Neem oil & $5 \%$ & $65.77 \mathrm{a}$ & $71.97 \mathrm{a}$ & $71.56 \mathrm{a}$ & $64.35 \mathrm{a}$ & $14.81 \mathrm{a}$ \\
\hline $\mathrm{T}_{6}$ Nitenpyrem & $100 \mathrm{ml} / \mathrm{Ha}$ & $72.15 \mathrm{a}$ & $73.01 \mathrm{a}$ & $71.55 \mathrm{a}$ & $64.71 \mathrm{a}$ & $12.67 \mathrm{a}$ \\
\hline $\mathrm{T}_{7}$ Water & Control & $4.05 \mathrm{e}$ & $3.87 \mathrm{e}$ & $4.66 \mathrm{e}$ & $-5.08 \mathrm{e}$ & $-1.65 \mathrm{~d}$ \\
\hline LSD Value & & 1.35 & 1.12 & 1.99 & 2.80 & 1.84 \\
\hline
\end{tabular}

Means followed by the same letters in the same column are not significantly different at $\mathrm{P}=0.05$.

Value with "-_" symbol represent an increase in the pest population.

\section{Discussion}

Different plant e4xtracts and chemical insecticides such as thiomethoxam, neonicotinoid, imedacloprid, Fipronil, fipronil and lambda Cyhalothrin were tested earlier for their toxicity against jassid and whitefly pests which attack okra fields (Begum et al., 2016; Pawar et al., 2016). Researchers reported that imedacloprid was the most effective insecticides as compared to all others tested (Ali et al., 2005; Preetha et al., 2009), whereas dimethoate was reported to be the most effective insecticide against jassids (Dabhi \& Koshiya, 2014).

In the current study, an experiment was conductive to check the comparative toxicity of neem oil and nitenpyrem using different concentrations against the okra jassid population. The significant variation of pest population was recorded in okra plant after chemical application. It was found that all doses of neem oil and nitenpyrem used were found effective against the jassid. The lowest concentration of neem oil $(1 \%)$ was least effective in reducing the jassid population, whereas the $5 \%$ concentration was the most effective. All tested concentrations were found toxic against jassid as compared to control. The study findings are in line with the results reported by previous workers (Rehman et al., 2015). The application of botanical extracts and chemical insecticides can influence insect pest population and total fruit weight (Ali et al., 2005; Indira Gandhi et al., 2006).

Neem oil is ecofriendly and effective botanical extract to control jassid in okra field, and it is recommended for application by farmers at the inception of pest population increase and proved to be an effective component of the integrated pest management strategy.

\section{Acknowledgement}

Authors are highly thankful to the farmer Mr. Masood Maqbool, for providing his field to conduct the study.

\footnotetext{
الملخص

ساجد، ذو النورين، محمد أنور الحق، قاسم فاروق، يعقوب سلطان، أسامة شاعر، محمد طيب ومحمد رمظان. 2021. مقارنة سمية المبيدين نايتبيريم وزيت النيم ضد نطاط الأوراق Amarasca bigutulla bigutullaa الذي يصيب محصول البامياء. مجلة وقاية النبات العربية، 39(3): 210-214. https://doi.org/10.22268/AJPP-039.3.210214 يعتبر نطاط الأوراق من الآفات الماصة المهمة على محصول البامياء. تم إجراء دراسة مقارتة عملية خلال العام 2018 لمعرفة كفاءة سمية المبيدين نايتتبيريم وزيت النيم لمكافحة نطاط الأوراق على محصول البامياء تحت الظروف الحقلية. أظهرت الدراسة أن بعد 24 ساعة من رش المبيد، وجد بأن المبيد نايتبيريم أكثر سمية وسبب خفض أعداد الآقة بـ 72.15\%. بينما وجد بأنه بعد 120 ساعة من رش زيت النيم 4\% تم خفض أعداد نطاط الأوراق بنسبة 15.05 \% فقط. وازدادت نسبة

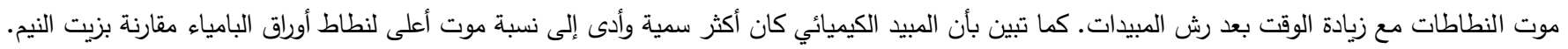

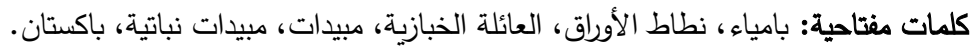

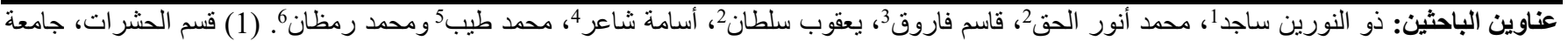

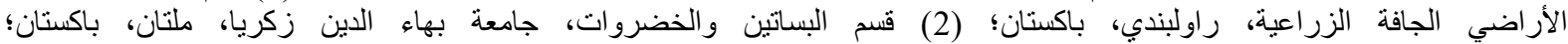

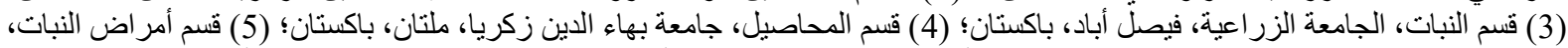

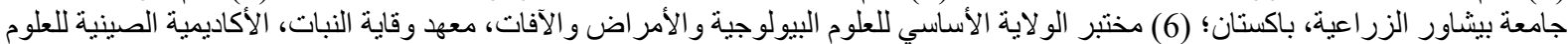

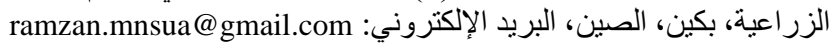




\section{References}

Ali, S., M.A. Khan, A. Habib, S. Rasheed and Y. Iftikhar. 2005. Management of yellow vein mosaic disease of okra through pesticide/bio-pesticide and suitable cultivars. International Journal of Agriculture and Biology (Pakistan), 7: 145-147.

Anaso, C.E. and N.E.S. Lale. 2001. Evaluation of aqueous neem kernel extract for the control of major insect pests of okra in Nigeria, Sudan savannah. Journal of Arid Agriculture, 11: 65-72.

Begum, K., S. Patil and P. Mohite. 2016. Evaluation of newer molecules of insecticides against sucking pests complex infesting okra. Indian Journal of Applied Research, 6(2): 30-34.

Dabhi, M.V. and D.J. Koshiya. 2014. Effect of abiotic factors on population dynamics of leafhopper, Amrasca biguttula biguttula (Ishida) in okra. Advance Research Journal of Crop Improvement, 5(1): 11-14.

Dhaliwal, G.S. 2004. Agricultural pests of South Asia and their management. Kalyani Publishers, New Delhi, India., $498 \mathrm{pp}$.

Dhandapani, N., U.R. Shelkar and M. Murugan. 2003. Bio-intensive pest management (BIPM) in major vegetable crops: an Indian perspective. Food, Agriculture and Environment, 2: 333-339.

Fajinmi, A.A. and O.B. Fajinmi. 2010. Incidence of okra mosaic virus at different growth stages of okra plants (Abelmoschus esculentus (L.) Moench) under tropical condition. Journal of General Molecular Virology, 2(1): 28-31.

Hassan, S., Y.A. Jesse and H.B. Gabdo. 2007. Pesticides utilization in Mubi area and associated health hazards: a survey. Journal of Sustainable Development in Agriculture \& Environment, 3: 89-95.

Indira Gandhi, P., K. Gunasekaran and T. Sa. 2006. Neem oil as a potential seed dresser for managing Homopterous sucking pests of Okra (Abelmoschus esculentus (L.) Moench). Journal of Pest Science, 79: 103-111. https://doi.org/10.1007/s10340-006-0122-0

Kahlon, T.S., M.H. Chapman and G.E. Smith. 2007. In vitro binding of bile acids by okra, beets, asparagus, eggplant, turnips, green beans, carrots, and cauliflower. Food Chemistry, 103(2): 676-680. https://doi.org/10.1016/j.foodchem.2006.07.056

Khattak, M.K., M. Rashid, S.A.S. Hussain and T. Islam. 2006. Comparative effect of neem (Azadirachta indica A. Juss) oil, neem seed water extract and baythroid TM against whitefly, jassids, and thrips on cotton. Pakistan Entomologist, 28(1): 31-37.

Kumar, S., S. Dagnoko, A. Haougui, A. Ratnadass, D. Pasternak and C. Kouame. 2010. Okra (Abelmoschus spp.) in west and central Africa: potential and progress on its improvement. African Journal of Agricultural Research, 525(25): 3590-3598.
Mahmood, K., S. Eijaz, M.A. Khan, A. Alamgir, S.S. Shaukat, Z. Memood and A. Sajjad. 2014. Effects of biopesticides against jassid Amrasca devastans (dist.) and white fly Bemisia tabaci (Genn.) on orka. International Journal of Biology and Biotechnology, 11: $161-165$.

Malik, M.U., H. Javeed and M. Ayyaz. 2015. Evaluation of Different Groundnut Arachis hypogea L. Cultivars Against Termit, Odontotermes obesus (Rambur) in Rawalpindi, Pakistan. Turkish Journal of Agriculture Food Science and Technology, 3: 448-452.

Memon, A.G., G.H. Abro and T.S. Syed. 2004. Varietal resistance of okra against Earias spp. Journal of Entomology, 1(1): 1-5. https://doi.org/10.3923/je.2004.1.5

Murtaza, G., M. Ramzan, M.U. Ghani, N. Munawar, M. Majeed, A. Perveen and K. Umar. 2019. Effectiveness of different traps for monitoring sucking and chewing insect pests of crops. Egyptian Academic Journal of Biological Sciences (A. Entomology), 12(6): 15-21. https://doi.org/10.21608/EAJBSA.2019.58298

Pawar, S.A., P.R. Zanwar, S.G. Lokare, R.P. Dongarjal and M.M. Sonkamble. 2016. Efficacy of newer insecticides against sucking pests of okra. Indian Journal of Entomology, 78(3): 257-259.

Preetha, G., T. Manoharan, T. Stanley and S. Kuttalam. 2009. Evaluation of imidacloprid against okra jassid, Amrasca biguttula biguttula (ishida) and whitefly, Bemisia tabaci (gennadius). Indian Journal of Enfornoiogv, 71(3): 209-214.

Rajput, M.H. 2004. Effect of biopesticides against sucking insect complex on cauliflower Brassica oleraceae L., M.Sc. Thesis, Tandojam: Sindh Agriculture University, $53 \mathrm{pp}$.

Ramzan, M., G. Murtaza, N. Munawar, Muaz, M. Majeed, M., A. Perveen, M. Aziz, F. Ibrahim and A. Ullahullah. 2020. Plant characters of brinjal genotypes in relation to incidence of Jassid Amrasca biguttula biguttula (Ishida). Indian Journal of Entomology, 82(1): 16-19. https://doi.org/10.5958/0974-8172.2020.00003.6

Rehman, H.R., M. Nadeem, M. Ayyaz and H.A. Begum. 2015. Comparative efficacy of neem oil and lambdacyhalothrin against whitefly (Bemesia tabaci) and Jassid (Amrasca Devastans Dist.) in okra field. Russian Agricultural Sciences, 41(2-3): 138-145. https://doi.org/10.3103/S1068367415020238

Saifullah, M. and M. Rabbani. 2009. Evaluation and characterization of okra (Abelmoschus esculentus L. Moench.) genotypes. SAARC Journal of Agriculture, 7: 92-99.

Schippers, R.R. 2000. African indigenous vegetable: An overview of the cultivated species. Natural Resources Institute/ACP-EU Technical Centre for Agricultural and Rural Cooperation, Chatham, UK. 
Senthil Nathan, S., M.Y. Choi, C.H. Paik, H.Y. Seo and K. Kalaivani. 2009. Toxicity and physiological effects of neem pesticides applied to rice on Nilaparvata lugens (Stal.), the brown planthopper. Ecotoxicology Environment Safety, 72: 1707-1713.

Sharma, H.C. and R. Ortiz. 2002. Host plant resistance to insects: an eco-friendly approach for pest management and environment conservation. Journal of Environmental Biology, 23(2): 111-135.

Received: December 28, 2020; Accepted: September 15, 2021
Singh, S.S, D. Choudhary, H. Sharma, R. Mahla, Y.S. Mathur and D.B. Ahuja. 2008. Effect of insecticidal modules against jassid and shoot and fruit borer in okra. Indian Journal of Entomology, 70: 197-199.

Singh, Y., A. Jha, S. Verma, V.K. Misra and S.S. Singh. 2013. Population dynamics of sucking insect pests and its natural enemies on okra agro-ecosystem in Chitrakoot region. African Journal of Agriculture Research, 8(28): 3814-3819.

https://doi.org/10.5897/AJAR12.1743

تاريخ الاستلام: 2020/12/28؛ تاريخ الموافقة على النشر: 2021/9/15 